\title{
Pengembangan Hortikultura Lahan Kering Berbasis Pertanian Organik Dengan Perbaikan Teknologi Budidaya Di Desa Kayangan Lombok Utara
}

\author{
Jayaputra*, IGM. Arya Parwata, Bambang Budi Santoso, I Komang Damar Jaya \\ Kelompok Peneliti Bidang Ilmu Pengembangan Pertanian Lahan Kering \\ Jurusan Budidaya Pertanian Fakultas Pertanian Universitas Mataram, Indonesia
}

\begin{abstract}
Article history
Received: 21 November 2019

Revised: 22 November 2019

Accepted: 28 November 2019

*Corresponding Author:

Jayaputra,

Kelompok Peneliti Bidang

Ilmu Pengembangan Pertanian

Lahan Kering,

Jurusan Budidaya Pertanian,

Fakultas Pertanian,

Universitas Mataram,

Mataram, Indonesia
\end{abstract}

Email: jaya_putra@unram.ac.id

\begin{abstract}
One important issue of agricultural development in the dry land area of North Lombok Regency is how to increase the Planting Index (IP) supported by the availability of sufficient water, especially for the development of horticultural commodities. The increase in the Planting Index is expected to lead to an increase in community welfare, specifically an increase in farmers' incomes. The development of horticulture is intended to provide added value to farmers' income by applying environmentally friendly Good Agricultural Practices with production management in accordance with the conditions of natural resources. One area of dry land that has sufficient potential for horticultural development in North Lombok Regency is Kayangan Village. Problems faced by dry land farmers include the level of knowledge and skills of farmers, especially in the management of horticultural commodities and the relatively low level of farmer participation. To overcome these problems, innovation technology transfer is needed through the development of environmentally friendly horticultural crops by regulating cropping systems and improving cultivation technology to increase farmers' incomes. Counseling and training, as well as demonstration plots for improved cultivation technology and regulation of horticultural cropping patterns were carried out during May-November 2019. Community service activities were considered quite successful in terms of the enthusiasm and perseverance of participants in participating in counseling and training, as well as demonstration plots (tomato plants, chili peppers, melons, intercropped tomatoes and pachoi). The results of the demonstration plot showed a significant increase both in crop productivity and increased income per unit area of arable land. On going assistance from all parties, especially the local government, is expected to sustainably develop horticultural commodities in order to increase the income of dry land farmers.
\end{abstract}

Keywords: crop index; environment; training; cropping patterns

Abstrak: Salah satu issu penting pembangunan pertanian di kawasan lahan kering Kabupaten Lombok Utara adalah bagaimana meningkatkan Indeks Pertanaman (IP) didukung oleh ketersediaan air yang cukup, terutama untuk pengembangan komoditas hortikultura. Meningkatnya Indeks Pertanaman diharapkan memicu peningkatan kesejahteraan masyarakat, khususnya pendapatan petani. Pengembangan hortikultura dimaksudkan untuk memberikan nilai tambah terhadap pendapatan petani dengan penerapan Teknologi Budidaya Pertanian yang Baik (Good Agricultural Practices) ramah lingkungan dengan manajemen produksi yang sesuai kondisi sumberdaya alam. Salah satu daerah berlahan kering yang cukup potensial untuk pengembangan hortikultura di Kabupaten Lombok Utara adalah Desa Kayangan. Permasalahan yang dihadapi 
oleh petani antara lain tingkat pengetahuan dan keterampilan petani dalam pengelolaan komoditas hortikultura dan tingkat partisipasi petani yang relatif masih rendah. Untuk mengatasi permasalahan tersebut, telah dilakukan transfer teknologi inovasi melalui pengembangan tanaman hortikultura yang ramah lingkungan dengan pengaturan sistem tanam dan perbaikan teknologi budidaya guna meningkatkan pendapatan petani. Penyuluhan dan pelatihan, serta demplot perbaikan teknologi budidaya dan pengaturan pola tanam komoditas hortikultura telah dilaksanakan selama Mei-Nopember 2019. Kegiatan pengabdian kepada masyarakat ini dinilai cukup berhasil dilihat dari antusiasme dan ketekunan peserta dalam mengikuti penyuluhan dan pelatihan, serta demplot (tanaman tomat, cabai, melon, tumpangsari tomat dan pachoi). Hasil pelaksanaan demplot menunjukan peningkatan yang nyata baik pada produktivitas tanaman maupun peningkatan pendapatan per satuan luas lahan garapan. Pendampingan yang berkelanjutan dari semua pihak terutama pemerintah setempat sangat diharapkan untuk keberlanjutan pengembangan komoditas hortikultura guna meningkatkan pendapatan petani lahan kering.

Kata kunci: indek pertanaman; kelor; lingkungan; pola tanam.

\section{PENDAHULUAN}

Pembangunan pertanian saat ini diarahkan kepada pembangunan pertanian yang berorientasi agribisnis, berwawasan lingkungan dan mampu menunjang upaya pengentasan kemiskinan serta peningkatan kualitas sumberdaya manusia. Pengembangan potensi sumberdaya alam suatu kawasan mempunyai nilai strategis. Salah satu issu penting pembangunan pertanian di kawasan/wilayah lahan kering Kabupaten Lombok Utara adalah bagaimana meningkatkan Indeks Pertanaman (IP) yang didukung oleh ketersediaan air yang cukup, terutama untuk pengembangan komoditas hortikultura yang selama ini masih dipasok atau didatangkan dari luar wilayah Kabupaten Lombok Utara. Meningkatnya Indeks Pertanaman di lahan kering diharapkan akan memicu peningkatan kesejahteraan masyarakat, khususnya peningkatan pendapatan petani sekaligus mempertahankan keberlanjutan sistem pertanian melalui konservasi tanah dan air.

Pembangunan pertanian melalui pengembangan komoditas hortikultura yang potensial di suatu wilayah merupakan salah satu upaya untuk meningkatkan perekonomian wilayah, yang pada akhirnya akan meningkatkan daya saing wilayah tersebut. Permasalahan yang dihadapi oleh petani lahan kering antara lain belum didukung oleh tersedianya infrastruktur irigasi yang memadai, tingkat pengetahuan dan keterampilan petani terutama dalam pengelolaan komoditas hortikultura yang sangat dibutuhkan untuk memenuhi kebutuhan masyarakat dan mendukung kebutuhan sektor pariwisata relatif masih rendah, tingkat partisipasi petani yang relatif masih rendah, rendahnya kepemilikan modal usaha yang dimiliki oleh petani dan belum adanya jaminan pasar bagi hasil-hasil hortikultura yang diproduksi oleh petani.

Masalahnya sekarang adalah wilayah potensial untuk pengembangan pertanian lahan kering terutama untuk pengembangan komoditas hortikultura di satu sisi belum banyak diketahui, sedangkan di sisi yang lain kawasan pengembangan pertanian lahan kering terutama untuk pengembangan kawasan komoditas hortikultura belum ada yang dijadikan sebagai rujukan. Oleh karena itu, mengkaji potensi pemanfaatan lahan kering terutama untuk pengembangan kawasan komoditas hortikultura untuk menunjang kebutuhan sektor pariwisata dan kebutuhan masyarakat secara luas menjadi sangat penting.

Pengembangan tanaman hortikultura, selain ditujukan peningkatan produksi komoditas, berhubungan juga dengan isu pembangunan pertanian secara umum, seperti permasalahan dalam 
usaha untuk meningkatkan produksi, mutu dan daya saing produk hortikultura, serta hubungannya dengan penerapan budidaya pertanian yang baik, penetapan pembagian daerah kawasan hortikultura seperti kawasan untuk buah buahan, sayur sayuran, penataan rantai pemasaran dan kelembagaan petani. Isu pertanian tersebut khususnya bidang hortikultura memerlukan pendekatan secara menyeluruh yang melibatkan berbagai lintas disiplin ilmu.( Zaenuri dkk,2017)

Penerapan Budidaya Pertanian yang Baik (Good Agricultural Practices) berdasarkan Peraturan Menteri Pertanian No. 61/Permentan/OT.160/ 11/2006, tanggal 28 November 2006, bertujuan: (1) Meningkatkan produksi dan produktivitas, (2) Meningkatkan mutu hasil pertanian termasuk keamanan konsumsi, (3) Meningkatkan efisiensi produksi dan daya saing, (4) Memperbaiki efisiensi penggunaan sumberdaya alam, (5) Mempertahankan kesuburan lahan, kelestarian lingkungan dan sistem produksi yang berkelanjutan, (6) Mendorong petani dan kelompok tani untuk memiliki sikap mental yang bertanggung jawab terhadap kesehatan dan keamanan diri dan lingkungan, dan (7) Memberi jaminan keamanan terhadap konsumen (Wibowo, 2000). Sedangkan sasaran yang akan dicapai adalah terwujudnya keamanan pangan, jaminan mutu, usaha agribisnis hortikultura berkelanjutan dan peningkatan daya saing. Semua tujuan yang tercantum di atas bermuara dari "pertanian berkelanjutan" yaitu memberdayakan sumber daya alam dan manusia untuk meningkatkan produksi dengan memperhatikan dan mempertahankan kelestarian lingkungan dan berkesinambungan (Utomo, 2002).

Salah satu daerah yang cukup potensial untuk pengembangan hortikultura di Kabupaten Lombok Utara adalah Desa Kayangan. Kondisi saat ini, sistem dan pola tanam usahatani yang diterapkan masyarakat tani di desa Kayangan masih tradisional menurut kebiasaan yang sudah turun temurun baik dari teknik budidaya, sistem dan pola tanam maupun dari segi pemilihan tanaman yang diusahakan serta pola pengusahaannya tidak intensif dan belum berorientasi pasar, khususnya tanaman hortikultura yang sangat potensial yang dapat dikembangkan sesuai daya dukung lahan dan iklim yang menunjang. Kondisi ini tentu berpengaruh terhadap masih rendahnya produktivitas pertanian dalam arti luas yang dihasilkan oleh petani, sehingga akan berpengaruh terhadap rendahnya penghasilan mereka. Pengembangan hortikultura dimaksudkan untuk memberikan nilai tambah terhadap pendapatan petani dengan penerapan Budidaya Pertanian yang Baik (Good Agricultural Practices) dan manajemen produksi yang sesuai dengan kondisi sumberdaya alam.

Berdasarkan uraian dia atas, maka telah dilakukan kegiatan pengabdian kepada masyarakat sebagai upaya untuk meningkatkan pengetahuan dan keterampilan petani di desa Kayangan dalam mengelola sumberdaya lahan lahan kering guna peningkatan pendapatan petani melalui pengembangan tanaman hortikultura berbasis pertanian organik dengan pengaturan sistem dan Pola Tanam serta Perbaikan Teknologi Budidaya. Program pengabdian kepada masyarakat ini dilaksanakan sejak Mei 2019 sampai dengan bulan September 2019 ini bertujuan untuk: 1) Melakukan transfer teknologi melalui kegiatan penyuluhan, pelatihan/ demplot, dan pendampingan masyarakat dalam rangka mengembangkan komoditi-komoditi hortikultura unggulan dan komoditi pendukung serta mendorong tumbuh kembangnya usaha agribisnis hortikultura di desa Kayangan yang berakar pada kemampuan sumberdaya lokal yang ada; 2) Meningkatkan kapasitas petani dan kelompok tani melalui bimbingan teknis dalam pengembangan lahan kering yang berkelanjutan dengan komoditas hortikultura sebagai komoditi andalan.

Meningkatkan status ekonomi masyarakat dengan mengembangkan potensi daerah melalui kegiatan transfer teknologi yang berkelanjutan. 


\section{METODE}

Kegiatan pengabdian kepada masyarakat ini dilaksanakan Dusun Beraringan Desa Kayangan Kecamatan Kayangan Kabupaten Lombok Utara. Peserta kegiatan adalah anggota kelompok Tani Lembah Telaga sebanyak 20 orang petani yang terdiri dari petani yang sudah pernah melakukan budidaya komoditas hortikultura dan petani yang belum pernah melakukan budidaya komoditas hortikultura. Penentuan petani binaan ini dilakukan oleh ketua kelompok tani lembah sembaga dan Tim PPM Fakultas Pertanian Universitas Mataram. Petani binaan yang dipilih adalah petani yang mempunyai motivasi untuk mengikuti kegiatan pengembangan lahan kering dengan basis pengembangan komoditas hortikultura sebagai komoditi andalan.

Sesuai dengan target luaran, maka dilakukan pengumpulan data dengan menggunakan metode observasi. Pelaksanaan kegiatan pengabdian kepada masyarakat ini menggunakan metode pendekatan sosial yang menempatkan masyarakat binaan sebagai subyek kegiatan dan metode kaji terap partisipatif (Participatory Action Reseach) pada tahap pelatihan kelompok tani binaan, dan praktik demonstrasi plot (demplot) untuk percepatan alih teknologi dan pembinaan langsung oleh tim pelaksana.

Pemberdayaan masyarakat dengan metode ini pada dasarnya adalah upaya pelibatan masyarakat untuk belajar dan beraktivitas secara berkelanjutan dalam rangka meningkatkan kualitas hidup mereka. Oleh karena itu, dalam kegiatan pengembangan hortikultura lahan kering yang berkelanjutan, masyarakat mulai dilibatkan dalam kegiatan perencanaan program, pelaksanaan program, pemanfaatan hasil program dan evaluasi terhadap pelaksanaan program. Dengan cara seperti ini, maka diharapkan kegiatan kaji terap partisipatif dalam pengembangan hortukultura lahan kering yang tersusun adalah program yang sesuai dengan kebutuhan masyarakat.

Kegiatan Penyuluhan dilaksanakan dengan cara ceramah disertai dengan presentasi menggunakan Power Point dan dikuti diskusi/ tanya jawab. Presentasi Power Point dimaksudkan untuk mempertegas maksud dari ceramah dan meberikan contoh-contoh teknik pengelolaan/ budidaya tanaman hortikultura dengan menampilkan secara visual penerapan berbagai teknologi budidaya tanaman hortikultura berbasis pertanian organik.

Selain dilakukan ceramah dan diskusi, kegiatan dilanjutkan dengan pelatihan/ demplot penerapan sistem dan pola tanam serta teknologi budidaya ramah lingkungan/ pertanian organik yang ditawarkan, di antaranya teknik budidaya berbagai komoditas tanaman hortikultura yang disesuaikan dengan kebutuhan masyarakat setempat dan pasar, serta pemanfaatan limbah rumahtangga, sisa-sisa tanaman, kotoran ternak untuk pembuatan kompos dan pengenalan tanaman lokal setempat yang potensi untuk pestisida hayati. Pengomposan mengikuti prosedur Djuarnani dkk (2005)

Untuk melakukan bimbingan secara intensif pada setiap kegiatan yang dilakukan oleh kelompok petani mitra binaan, maka dilakukan pendampingan di lapangan. Tim PPM Fakultas Pertanian Universitas Mataram berperan sebagai tenaga ahli yang melakukan transfer pengetahuan dan teknologi di lapangan yang dilakukan setiap 1 kali seminggu.

Evaluasi merupakan kegiatan akhir program pengabdian kepada masyarakat yang dilakukan terhadap peran dan keterlibatan peserta, antusiasme serta serapan peserta terhadap kegiatan penyuluhan, demplot dan bimbingan yang telah dilakukan.

\section{HASIL DAN PEMBAHASAN}

Sesuai dengan tujuan yang telah ditetapkan dan metode pelaksanaan kegiatan, pelaksanaan program pengabdian kepada masyarakat ini dilaksanakan dengan tahapan sebagai berikut: 


\section{Tahap persiapan}

Tahap persiapan dimulai sejak bulan Mei 2019 sampai awal bulan Juli 2019 menjelang pelaksanaan kegiatan penyuluhan dan pelatihan/demplot. Pada tahap ini, telah dilakukan pendekatanpendekatan dengan berbagai unsur dalam masyarakat seperti tokoh masyarakat, tokoh pemuda, kelompok tani dan pemerintahan desa. Beberapa hal yang dilakukan pada tahap persiapan meliputi:

a. Observasi dan Sosialisasi program kegiatan kepada masyarakat. Kegiatan ini dilakukan untuk mengidentifikasi potensi wilayah dan penyamaan persepsi dengan berbagai unsur dalam masyarakat seperti tokoh masyarakat, tokoh pemuda dan pemerintahan desa. Penyamaan persepsi ini berkaitan dengan potensi sumberdaya manusia dan potensi sumberdaya alam yang bisa dan akan dikembangkan oleh masyarakat, kondisi sosial ekonomi, budaya, kondisi ketersediaan air, pola pemanfaatan lahan kering, penerapan teknologi anjuran atau teknologi budidaya yang sudah dilaksanakan oleh masyarakat, peluang pasar dan jaringan pemasaran hasil pertanian, SDM, keterampilan, pengetahuan dan sarana prasarana pendukung lainnya.

b. Penetapan petani yang akan menjadi mitra binaan sasaran program kegiatan kegiatan pengabdian kepada masyarakat. Petani yang dipilih adalah petani yang mempunyai motivasi untuk mengikuti kegiatan pengembangan lahan kering dengan basis pengembangan komoditas hortikultura sebagai komoditi andalan dan memiliki kemauan untuk memperbaiki teknologi budidaya serta meningkatkan produktivitas lahan pertaniannya. Penentuan petani binaan ini dilakukan oleh ketua kelompok tani sesuai saran dan persyaratan yang telah ditetentukan oleh Tim Pelaksana.

c. Penetapan waktu pelaksanaan kegiatan penyuluhan dan pelatihan/ demplot pengembangan hortikultura dengan pengaturan sistem tanam dan perbaikan teknologi budidaya berbasis pertanian organik. Pelaksanaan penyuluhan disepakati dilakukan tanggal 21 Juli 2019 dan pelaksanaan Demplot dilaksanakan pada bulan Agustus 2019.

d. Persiapan/pengadaan bahan dan alat untuk kegiatan penyuluhan dan demplot.

\section{Tahap Pelaksanaan}

Tahap pelaksanaan meliputi kegiatan Penyuluhan, Pelatihan/ Demplot dan Pendampingan. Kegiatan penyuluhan dilakukan pada tanggal 21 Juli 2019 yang berlangsung sejak pukul 16.00 sampai pukul 18.15 di dusun beraringan desa kayangan, dengan menyampaikan materi secara langsung oleh Tim PPM yang diikuti diskusi/ tanya jawab terhadap materi yang disampaikan dan permasalahan yang dialami masyarakat sasaran dalam budidaya dan pengembangan tanaman hortikultura berbasis pertanian organik. Penyampaian materi penyuluhan dilakukan melalui media dalam bentuk powerpoint yang ditanyangkan melalui LCD proyektor.

Pelaksanaan kegiatan pelatihan/ demplot pemanfaatan limbah rumahtangga, sisa-sisa tanaman, kotoran ternak untuk pembuatan kompos dan pengenalan tanaman lokal setempat yang potensi untuk pestisida hayati dilakukan berselang 1 (satu) minggu berikutnya setelah kegiatan penyuluhan dilaksanakan sesuai kesepakatan dan untuk mempersiapkan bahan-bahan dan alat yang diperlukan untuk kegiatan demonstrasi. Sedangkan demplot penerapan teknologi budidaya hortikultura ramah lingkungan/ pertanian organik berbagai komoditas tanaman hortikultura (tomat, cabai dan melon) dan sistem/pola tanam di lahan demplot teknik budidaya dilaksanakan 14 hari kemudian setelah kegiatan demplot pembuatan kompos, sambil menunggu kesiapan lahan (pengolahan tanah dan pembuatan bedengan) dan bibit semaian siap pindah tanam. Tujuan dari kegiatan ini adalah untuk meningkatkan pengetahuan dan pemahaman dan keterampilan kelompok masyarakat sasaran tentang cara-cara melakukan pembuatan pupuk organik dan pestisida hayati serta teknik budidaya tanaman secara 
organik dengan mengembangkan berbagai jenis tanaman hortikultura terutama sayur-sayuran baik di lahan sawah maupun lahan pekarangan menggunakan polibag. Pelatihan/ demonstrasi dilakukan dengan memberikan petunjuk dan praktek langsung dalam hal teknik pembuatan pupuk organik dan teknik budidaya tanaman secara organik baik di lahan sawah maupun di lahan pekarangan menggunakan polibag, dimulai dari persiapan bahan dan alat, pembuatan kompos, pencampuran bahan untuk media tanam, persemaian, persiapan lahan, pengisian polibag dengan media tanam, penanaman, sistem penanaman, pengaturan media tanam dan penerapan sisitem pertanian organik. Sasaran pelatihan/ demonstrasi pembuatan pupuk organik adalah untuk digunakan sebagai bahan pemupukan tanaman hortikultura yang diusahakan. Sedangkan pengembangan komoditi tanaman hortikultura terutama sayuran baik di lahan sawah maupun di lahan pekarangan menggunakan polibag ditujukan sebagai salah satu alternatif upaya diversifikasi komoditas tanaman yang dapat dikembangkan di lahan kering untuk meningkatkan pendapatan dan memenuhi kebutuhan sehari-hari.

Bahan dan alat untuk keperluan demonstrasi telah dipersiapkan sebelumnya oleh TIM pengabdian kepada masyarakat, seperti: starter untuk pengomposan (EM-4 dan stardec), benih sayuran tomat, melon, cabai, sawi, selada, dan benih sayuran lainnya, polibag, mulsa plastik, hand sprayer, contoh kompos, pupuk dan pestisida organik. Sementara alat dan bahan lainnya disiapkan masyarakat peserta seperti cangkul, media tanah, kotoran ternak bambu dan lain-lain. Demplot teknik budidaya secara organik di lahan sawah dilakukan pada luasan lahan kurang lebih 7 are per komoditi dengan pemilihan tanaman tomat, melon dan cabai sebagai tanaman demplot. Populasi tanaman masingmasing sebanyak 1000 pohon.

Dalam pelaksanaan penyuluhan, pelatihan/ demontrasi pembuatan pupuk organik (kompos) dan teknik budidaya tanaman berbasis pertanian organik, respon peserta cukup besar, hal ini dapat dilihat dari keseriusan dan ketekunan seluruh peserta untuk mengikuti proses pelatihan/ demonstarasi tersebut.

Dalam rangka menindaklanjuti kegiatan penyuluhan dan pelatihan/ demonstrasi tersebut, TIM pelaksana pengabdian kepada masyarakat melakukan monitoring secara berkala dan berkelanjutan untuk memberikan arahan dan mengatasi masalah yang dihadapi masyarakat sasaran berkaitan dengan pengelolaan tanaman secara organik baik di lahan sawah maupun di lahan pekarangan.

\section{Sistem Tanam dan Perbaikan Teknologi Budidaya Tanaman Hortikultura}

Tanaman hortikultura dapat diusahan di lahan sempit maupun skala besar (Utomo, 2002). Oleh karena itu, diperlukan suatu sistem agar produk pertanian terutama hortikultura dapat berkesinambungan, dengan perencanaan yang juga berkelanjutan.

Kendala dalam pengembangan tanaman hortikultura di lokasi kegiatan adalah: pertama, lahan pertanian berada di dataran rendah dengan ciri lahan kering, poros dan terbatasnya ketersediaan air. Selain itu, kepemilikan lahan yang relatif kecil mengakibatkan kesulitan tersendiri bagi petani untuk mengembangkan sistem pertaniannya, serta keterbatasan pengetahuan cara budidaya hortikultura dan juga permodalan. Untuk mengatasi hal tersebut diperlukan adanya demplot pengembangan hortikultura dengan berbagai macam cara sistem budidaya yang bertujuan untuk meningkatkan produktivitas lahan, memanfaatkan sumberdaya seefisien mungkin, dan yang terpenting adalah strategi mensiasati fluktuasi harga yang cukup tajam dengan pengaturan penjadwalan tanam yang tepat dan pola/sistem tanam yang diterapkan. Teknik budidaya di dalam pengembangan dan pemilihan tanaman hortikultura yang sesuai diharapkan dapat meningkatkan produktivitas lahan dan sekaligus meningkatkan pendapatan. 
Sistem atau pola tanam budidaya hortikultura yang diterapkan di lahan demplot di Dusun Beraringan Desa Kayangan, dibagi menjadi:

1. Sistem Monokultur, sistem ini dilakukan pada lahan kurang lebih 7 are untuk masing-masing tanaman (tomat, melon dan cabai), dengan pemeliharaan intensif, dan dengan memperhatikan input yang diaplikasikan. Kriteria penggunaan input, dilakukan seefisien mungkin, seperti dalam penggunaan air irigasi, selain dilakukan dengan cara leb (penggenangan) juga dilakukan dengan cara "penyiramanr" menggunakan gembor dari sumber air bak penampungan menggunakan terpal sehingga penggunaan air akan menjadi lebih effisien. Pemeliharaan tanaman dilakukan secara intensif dan penggunaan pestisida yang didasarkan pada manajemen pengelolaan hama dan penyakit dengan mengutamakan penggunaan pestisida organik, sehingga lingkungan tidak tercemar dan produk yang dihasilkan aman.

2. Sistem Tanam Seri, yaitu menanam tanaman sejenis secara berkesinambungan, penanaman (tomat) seri ke dua dilakukan saat tanaman seri pertama berumur 30 hari setelah tanam (tanaman sudah mulai berbunga), dan penenaman tomat seri ke tiga dilakukan 30 hari setelah penanaman seri ke dua, demikian seterusnya. Sehingga sejak panen seri pertama produksi tomat selalu tersedia setiap saat sepanjang tahun. Cara ini diterapkan untuk mengatasi fluktuasi harga. Kondisi ini diharapkan mampu meminimalisir kerugian bagi petani ketika terjadi penurunan harga pada suatu waktu, dan mendapatkan keuntungan pada waktu yang lain karena terjadinya fluktuasi harga di pasaran yang cukup tajam.

3. Sistem Tumpang Sari. Sistem ini dilakukan untuk memanfaatkan lahan yang masih kosong sambil menunggu tanaman utama panen. Pada Demplot yang dilakukan adalah menanam tanaman yang berumur pendek diantara tanaman utama yang berumur relatif panjang (Pachoi ditanam di antara tanaman tomat). Tanama Pachoi dipanen pada umur 35 bulan setelah tanam sementara tanaman tomat memasuki fase geneatif (mulai berbunga dan pembentukan buah). Sehingga petani dapat panen pachoi sebelum panen tomat. Penanaman sistem ini dapat meningkatkan nilai LER (Land equivalesi Ratio) yaitu nilai tanaman tumpang sari terhadap tanaman yang ditanam secara monokultur. Hal ini berarti produktivitas lahan dapat ditingkatkan.

Pemilihan tanaman hortikultura yang dikembangkan di lahan kering lokasi kegiatan didasarkan pada beberapa hal, Pertama, bahwa tanaman tersebut sesuai untuk daerah tersebut, sehingga tanaman yang usahakan adalah tanaman dataran rendah, yang mampu bertahan dengan temperatur yang cukup tinggi. Kedua, benih atau bibit tanaman mudah diperolah. Hal ini diperlukan apabila tanaman tersebut berhasil dibudidayakan dan akan dikembangkan lebih lanjut oleh masyarakat. Selanjutnya, nilai ekonomi atau harga produk tanaman tersebut cukup tinggi.

Hasil Demplot beberapa komoditi hortikultura (Tomat, Melon dan Cabai) menunjukkan bahwa dengan melakukan efisiensi penggunaan air dan pengelolaan budidaya secara baik dan benar sesuai dengan kondisi agroklimat lahan kering setempat serta pendampingan yang intensif, produktivas tanaman yang dibudidayakan (demplot) mampu memberikan hasil yang maksimal. Dengan melihat dan mengamati pertumbuhan dan perkembangan tanaman tomat dan perolehan hasil yang cukup memuaskan tersebut, para petani binaan menjadi sangat tertarik untuk pengembangan lebih lanjut (duplikasi kegiatan demplot), namun mereka terkendala dengan modal awal (usahatani), terlebih dengan kejadian Gempa yang terjadi secara merata di KLU tahun lalu sangat berdampak terhadap kehidupan masyarakat, dan mereka masih sangat mengharapkan pendampingan adialebih lanjut. Hal ini menunjukkan bahwa pada dasarnya masyarakat sadar dan mau berbuat untuk mengembangkan 
tanaman hortikultura berbasis pertanian organik tidak hanya untuk meningkatkan pendapatannya tetapi juga untuk mendukung terbentuknya sistem pertanian ramah lingkungan, asalkan mereka diberikan keyakinan dan pendampingan yang berkelanjutan karena mereka sudah melihat secara langsung hasil nyata dari kegiatan pengabdian ini. Oleh karena itu bimbingan dan pendampingan yang berkelanjutan terutama dari aparat pemerintah desa setempat dan instansi terkait sangat diperlukan. Lebih lanjut tentunya diperlukan kegiatan yang mengarah pada penguatan kelembagaan kelompok sehingga penanganan kawasan budidaya berbagai jenis komoditas tanaman hortikultura dapat dilakukan secara teratur dan berkelanjutan serta selalu memberikan nilai tambah untuk peningkatan ekonomi bersama.

Kendala-kendala dalam budidaya tanaman yang ditemui di lapangan dan cara mengatasinya dapat dikemukakan sebagai berikut:

Lahan usahatani di lokasi pengabdian kepada masyarakat dusun Beraringan desa Kayangan kecamatan Kayangan KLU merupakan lahan kering dengan kendala utama keterbatasan air, umumnya hanya dapat diusahakan satu kali dalam setahun yaitu pada musim penghujan, dan hanya di beberapa titik lokasi kegiatan budidaya dapat dilakukan pada musim kemarau dengan memanfaatkan sumur bor sebagai sumber air pengairan. Meskipun terdapat sumur bor di beberapa titik lokasi, petani belum dapat memanfaatkannya secara optimal karena keterbatasan modal usahatani dan mereka beranggapan penggunaan sumur bor sebagai sumber air pengairan usahatani sangat membebani biaya produksi tidak sebanding dengan hasil yang diperoleh. Jenis tanaman yang diusahakan juga sangat terbatas, seperti padi, tanaman jagung, dan kacang tanah serta beberapa jenis tanaman hortikultura seperti sayuran: tomat, cabai, dan kacang panjang. Pola penanaman dengan jenis komoditas tersebut tidak mengalami perkembangan dari tahun ke tahun karena pengetahuan dan keterampilan petani yang masih sangat terbatas mengenai teknologi budidaya berbagai komoditas yang lebih prospek menguntungkan untuk diusahakan di lahan usaha taninya (lahan kering) sesuai dengan daya dukung lingkungan/ ketersediaan sumberdaya setempat.

Selama ini kegiatan budidaya tanaman umumnya masih bersifat tradisional dengan ketergantungan yang sangat tinggi dalam penggunaan pupuk dan pestisida kimia untuk menunjang pertumbuhan dan hasil tanamannya. Dengan semakin mahalnya saprodi pertanian terutama pupuk dan pestisida kimiawi, maka biaya produksi dalam budidaya tanaman akan semakin tinggi dan kondisi ini tentu dirasakan sangat berat bagi petani dalam menyediakan modal awal usahatani terutama bagi masyarakat miskin (petani). Penggunaaan pupuk organik seperti kompos hampir tidak pernah dilakukan, padahal ketersediaan bahan-bahan organik untuk kompos banyak tersedia di lokasi setempat seperti kotoran ternak dan sisa-sisa tanaman bahkan sebagian ketersediaannya sudah siap pakai (sudah mengalami proses penguraian secara alami). Berbagai alasan mereka tidak memanfaatkan bahan-bahan organik tersebut, antara lain: belum memahami manfaat dari bahanbahan organik, hasil produksi tanaman lebih nyata bila menggunakan pupuk anorganik dan pestisida kimia, pupuk anorganik dan pestisida kimia mudah mereka peroleh serta praktis dalam penggunaannya. Meskipun dalam kenyataannya penggunaannya kebanyakan tidak sesuai dengan anjuran serta tidak memperhatikan aspek keamanan karena tidak dilandasi oleh pengetahuan yang cukup mengenai karakteristik tanaman, OPT dan bahaya penggunaan bahan kimiawi.

Dengan kondisi keterbatasan/ kendala lahan pertanian serta pengelolaan budidaya tanaman yang masih bersifat tradisional tersebut, produktivitas tanaman yang diusahakan sangat rendah di bawah produktivitas rata-rata. Hal ini tentu akan berdampak terhadap rendahnya pendapatan petani. 
Di sisi lain, dengan penggunaan pupuk dan pestisida kimia yang sangat intensif tentu akan berdampak terhadap pencemaran lingkungan.

Berdasarkan fakta dan identifikasi di lapangan maka permasalahan utama yang dihadapi masyarakat miskin dalam berusahatani terutama dikaitkan dengan upaya pengembangan tanaman hortikultura, antara lain: Ketersediaan air yang sangat terbatas, Pengetahuan dan penguasaan teknologi budidaya serta pola tanam dan Etos Kerja masyarakat tani yang rendah, keterbatasan modal awal untuk usahatani dan masalah pemasaran hasil pertanian.

Dalam budidaya tanaman, terutama tanaman hortikultura, ketersediaan air yang cukup selama proses produksi merupakan faktor utama yang menentukan kuantitas maupun kualitas hasil (keberhasilan usahatani). Untuk memenuhi kebutuhan pengairan tanaman khususnya pada musim kemarau, air diperoleh dari sumber Sumur Bor dengan sistim bayar sebesar Rp.50.000 per jam hanya mampu mengairi lahan penanaman seluas 10 are. Biaya pengairan menggunakan sumur bor ini dirasakan berat atau mahal oleh petani disebabkan mereka hanya melakukan pengairan mengandalkan sistem leb (menggenangi areal penanaman) dan dilakukan dengan frekuensi yang cukup tinggi untuk memenuhi kebutuhan air bagi tanaman dengan kondisi lahan kering (Entisol pasiran). Masalah keterbatasan air tersebut dapat diatasi dengan inovasi membuat bak penampungan air sederhana menggunakan alas penampung dari terpal ukuran 4x6 meter ${ }^{2}$ (daya tampung air $\mathrm{lb}$ 5000 liter). Bak penampungan diisi terlebih dahulu pada saat pengairan sistem leb yang dilakukan 2 minggu sekali, sehingga rentang waktu sampai pengairan leb berikutnya, di areal pertanaman masih tersedia air untuk mengairi tanaman bila diperlukan, menggunakan gembor. Dengan cara seperti ini tanaman tidak akan kekurangan air selama pertumbuhannya. Bak penampungan air ini mampu untuk mengatasi kebutuhan air bagi tanaman setelah pengairan leb selama 2 minggu untuk luas areal tanam kurang lebih 10 are $(0,1 \mathrm{Ha})$. Oleh karena itu bak penampungan air ini perlu dibuat untuk setiap luasan 10 are areal penanaman. Prinsip pokok dalam pengunaan air dalam budidaya tanaman di lahan kering adalah efektifitas dan efisiensi yang didasarkan pada kebutuhan tanaman budidaya. Oleh karena itu teknik efisiensi penggunaan air ini hanya akan efektif bila petani memahami karakteristik tanaman (relatif berbeda antar jenis tanaman yang satu dengan tanaman yang lainnya) kaitannya dengan ketersediaan serta pemenuhan kebutuhan air pada setiap fase pertumbuhan dan perkembangan tanaman.

Pengetahuan dan penguasaan teknologi budidaya tanaman yang masih rendah serta pengelolaan yang masih bersifat tradisional tersebut memberikan andil yang cukup besar dalam mempengaruhi Etos Kerja Masyarakat tani, dimana penanganan budidaya tanaman tidak dilakukan secara intensif dan banyak waktu luang tersisa tidak dimanfaatkan secara produktif, hal ini menyebabkan produktivitas tanaman yang diusahakan masih jauh dari rata-rata produksi tanaman di daerah lain terlebih lagi dibandingkan dengan potensi hasil tanaman yang dibudidayakan. Hal ini terkait erat dengan kurangnya informasi yang diperoleh oleh petani tentang teknik budidaya yang baik dan benar serta ramah lingkungan. Masalah ini diharapkan dapat diatasi dengan melibatkan petani secara aktif dalam kegiatan budidaya (demplot) yang dimulai dari kegiatan perencanaan, persiapan lahan, persemaian, penanaman, pemeliharaan tanaman sampai panen dan pemasaran hasil. Untuk merubah mindset petani hingga mau dan mampu dalam menerapkan dan melaksanakan serta menekuni Teknologi Budidaya Maju maka perlu dilakukan penyuluhan dan pendampingan secara intensif dengan berpegang pada Standar Operasional Prosedur (SOP) masing-masing tanaman budidaya yang dalam pelaksanaanya disesuaikan dengan status lahan dan kondisi agroklimat setempat (SOP budidaya tanaman spesifik lokasi). 

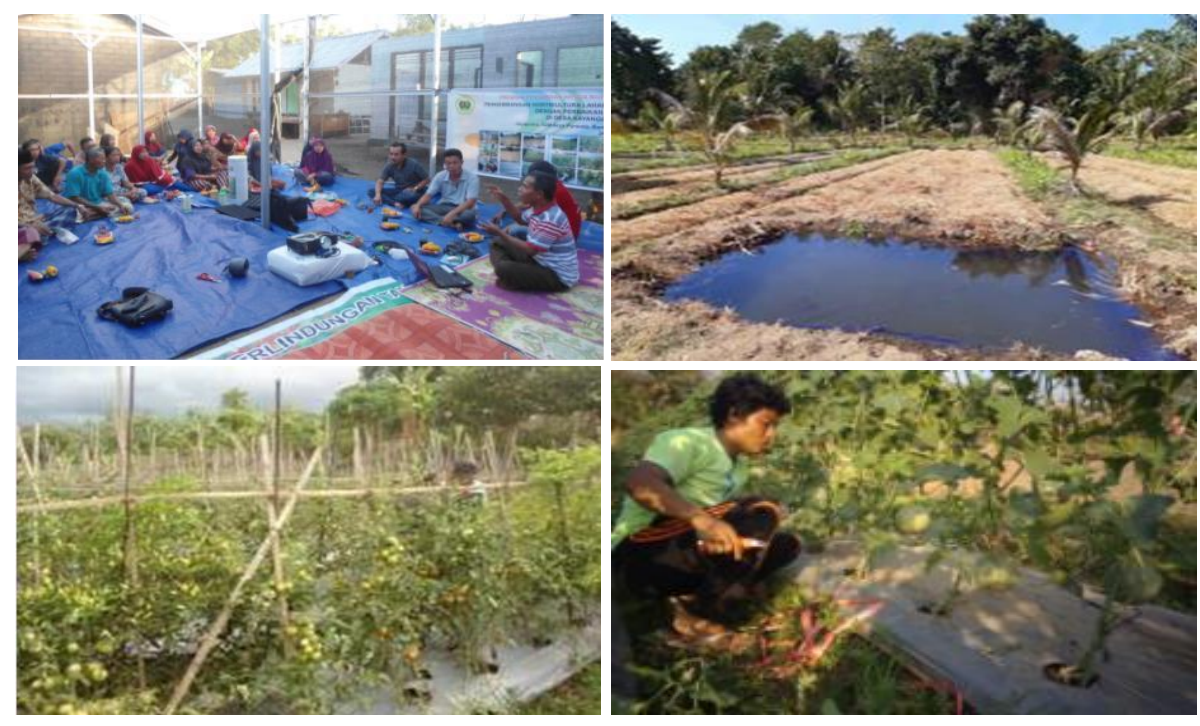

Gambar 1. Kegiatan pengabdian kepada masyarakt, searah jarum jam dari atas, kegiatan penyuluhan dan pelatihan, salah satu fasilitas pengairan hasil gotong royong, praktek bercocok tanam melon, dan keragaan pertumbuhan tanaman tomat hasil demplot selama kegiatan pengabdian kepada masyarakat di Dusun Beraringan, Desa Kayangan

Keterbatasan modal awal dan masalah pemasaran hasil dalam berusahatani seringkali menjadi alasan utama masyarakat miskin (petani) tidak memanfaatkan lahan yang dimiliki secara optimal dengan komoditas hortikultura yang memiliki nilai ekonomi tinggi karena membutuhkan biaya usahatani yang lebih tinggi. Mereka cenderung memilih tanaman yang sudah biasa mereka tanam (jagung, kacang tanah, dan beberapa komoditas hortikultura) dengan pertimbangan biaya produksi terjangkau, teknik pengelolaannya sudah terpola secara turun temurun (masih tradisional, minim inovasi teknologi budidaya), dan mudah dipasarkan. Mahalnya biaya saprodi pertanian berakibat pada semakin terbatasnya modal usahatani sehingga dengan modal yang mereka miliki tidak mampu untuk menyokong biaya-biaya produksi yang seharusnya dikeluarkan. Keadaan tersebut menyebabkan proses produksi tidak dapat dilakukan secara intensif, pemupukan terpaksa dilakukan tidak sesuai dengan anjuran bahkan tidak melakukan pemupukan sama sekali serta pengendalian pengganggu tanaman tidak dapat dilakukan sebagaimana mestinya karena tingginya harga pestisida. Keadaan ini akan berpengaruh terhadap produktivitas tanaman yang diusahakan baik kuantitas maupun kualitas. Apabila masalah pengetahuan dan penguasaan teknologi budidaya serta etos kerja masyarakat mampu ditingkatkan, maka permasalahan modal awal usahatani dan jaminan pemasaran menjadi faktor penentu upaya peningkatan pendapatan petani dapat ditingkatkan melalui peningkatan produktivitas tanaman dan pemilihan komoditas yang bernilai ekonomi tinggi. Pinjaman lunak dari pihak terkait menjadi solusi pemecahan masalah.

Kendala-kendala dalam berusahatani tersebut merupakan satu kesatuan yang mempengaruhi pola usahatani dan teknologi budidaya yang diterapkan petani di KLU. Oleh karena itu dalam upaya meningkatkan pendapatan / kesejahteraan masyarakat melalui peningkatan produktivitas tanaman budidaya yang diusahakan masyarakat maka tidak hanya perbaikan teknologi budidaya yang diperlukan tetapi juga faktor lain yang berkaitan dan menunjang harus ditangani secara terintegrasi, 
memerlukan kerja bersama lintas sektoral untuk mencapai tujuan peningkatan produktifitas usahatani.

\section{Tahap Evaluasi}

Evaluasi merupakan kegiatan akhir program pengabdian kepada masyarakat yang dilakukan terhadap peran dan keterlibatan peserta, antusiasme serta serapan peserta terhadap materi kegiatan penyuluhan, demplot dan bimbingan yang telah dilakukan. Dalam pelaksanaan kegiatan ini tidak mendapatkan hambatan yang berarti, namun karena tingkat pendidikan dan pengalaman para peserta yang berbeda-beda, sehingga respon mereka terhadap penerimaan materi juga berbeda-beda. Untuk mengatasi masalah tersebut, penyampaian materi harus dilakukan dengan bahasa yang sederhana dan lebih banyak menggunakan bahan peraga atau lebih banyak menunjukkan contoh - contoh kasus secara langsung.

Minat dan perhatian peserta dalam mengikuti kegiatan penyuluhan dan pelatihan/demplot yang cukup tinggi merupakan faktor pendorong yang kuat dalam proses penyelenggaraan kegiatan pengabdian kepada masyarakat ini. Disamping itu adanya dukungan dari aparat desa terutama dari Kepala Desa dan Kepala Dusun, dan ibu-ibu rumah tangga petani yang cukup kuat.

Dari hasil pengamatan selama berlangsungnya kegiatan penyuluhan, demplot dan pendampingan dapat disimpulkan beberapa hal sebagai berikut:

1. Respon peserta penyuluhan cukup besar, hal ini dapat dilihat dari keseriusan dan ketekunan seluruh peserta untuk mengikuti proses penyuluhan. Hal ini tentu dapat menjadi bekal tambahan pengetahuan mereka terkait upaya pengembangan tanaman hortikultura dan teknologi budidayanya.

2. Materi yang disampaikan cukup relevan dengan kebutuhan peserta, dan mudah dimengerti oleh peserta, hal ini dapat dilihat dari diskusi dan pertanyaan-pertanyaan yang diajukan oleh peserta cukup relevan dengan topik yang dibahas dan dipraktikkan.

Waktu yang disediakan dalam kegiatan ini terutama untuk dialog dirasa kurang, sehingga para peserta merasa sangat perlu untuk menindak lanjuti pertemuan tersebut. Oleh karena itu dukungan dari pemerintah setempat terutama dari aparat desa dan PPL sangat diperlukan untuk memfasilitasi penyelenggaraan tindak lanjut pertemuan dan pembinaan selanjutnya.

\section{KESIMPULAN DAN SARAN}

Perubahan prilaku masyarakat dalam bercocok tanam tanaman hortikultura yang baik merupakan tujuan dari pemberdayaan ini. Oleh karena itu, proses ini membutuhkan waktu yang lama untuk menilai apakah program ini sudah dapat dinilai berhasil atau tidak. Namun demikian dilihat dari antusiasme dan ketekunan peserta selama penyuluhan dan pelatihan, serta demplot, maka kegiatan pengabdian kepada masyarakat ini dapat dinilai cukup berhasil.

Teknologi budidaya tanaman hortikultura berbasis pertanian organik dan ramah lingkungan bagi masyarakat sasaran merupakan suatu hal yang dianggap sebagai inovasi atau teknologi baru. Sehingga melalui penyuluhan dan pelatihan, serta demplot yang telah dilakukan oleh tim PPM diharapkan bahwa inovasi dan teknologi ini mampu diadopsi oleh masyarakat sasaran.

Kegiatan PPM dalam rangka pengembangan tanaman hortikultura berbasis pertanian organik dengan teknologi budidaya yang sesuai dalam rangka peningkatan pendapatan petani seperti ini perlu dilakukan secara berkelanjutan sehingga dapat terinternalisasi dalam kehidupan masyarakat. Inovasi dan teknologi tersebut bukan hanya teradopsi oleh peserta penyuluhan dan pelatihan, serta demplot, 
tetapi diharapkan mampu direplikasi oleh masyarakat yang berminat untuk mengembangkan, bahkan diharapkan terjadi proses diffusi inovasi di kalangan masyarakat luas.

\section{Ucapan Terima Kasih}

Penulis mengucapkan terima kasih kepada Universitas Mataram, atas pendanaan kegiatan pengabdian kepada masyarakat ini melalui Dana BLU (PNBP) Universitas Mataram tahun 2019.

\section{DAFTAR PUSTAKA}

Djuarnani, N., Kristian B. S., Setiawan. 2005. Cara Cepat Membuat Kompos. Agromedia Pustaka. Higa, T. 1998. Materi Latihan Teknologi EM. Departemen Pertanian, Jakarta.

Rizal, M dan Fiana, Y. 2015.Teknologi Budidaya Tanaman Sayuran dan Toga di Perkotaan dan Pedesaan pada Kawasan Rumah Pangan Lestari dalam mendukung Ketahanan Pangan di Kalimantan Timur. Prosiding Seminar Nasional Masyarakat Biodiversitas Indonesia. Volume 1, Nomor 2, April2015.

Utomo M. 2002. Pengelolaan Lahan Kering untuk Pertanian Berkelanjutan. Makalah Disampaikan pada Seminar Nasional Pengembangan Wilayah Lahan Kering Tanggal 27-28 Mei 2002 di Hotel Lombok Raya Mataram. Mataram, Provinsi NTB.

Wibowo, R. 2000. Pertanian dan Pangan, Bunga Rampai Pemikiran menuju Ketahanan Pangan. Sinar Harapan. Jakarta.

Zainuri, Taslim sjah, Jayaputra dan Ahmad Sauqi. 2017. Pengembangan Agrowisata Melalui Sistem Agribisnis Dan Agroindustri Terpadu Untuk Mendukung Pariwisata Dan Ekonomi Desa Kayangan Kabupaten Lombok Utara. Laporan Penelitian MP3EI Tahun ke 2. Universitas Mataram. 